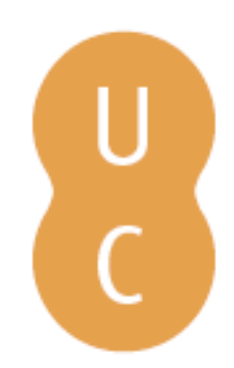

\title{
pompalina
}

\section{Dancing with Plutarch: dance and dance theory in Plutarch's Table Talk}

Autor(es): Jesus, Carlos A. Martins de

Publicado por: Imprensa da Universidade de Coimbra; Centro de Estudos Clássicos e

URL

persistente: URI:http://hdl.handle.net/10316.2/32027

DOI: $\quad$ DOI:http://dx.doi.org/10.14195/978-989-8281-17-3_37

Accessed : $\quad$ 26-Apr-2023 11:23:10

A navegação consulta e descarregamento dos títulos inseridos nas Bibliotecas Digitais UC Digitalis, UC Pombalina e UC Impactum, pressupõem a aceitação plena e sem reservas dos Termos e Condições de Uso destas Bibliotecas Digitais, disponíveis em https://digitalis.uc.pt/pt-pt/termos.

Conforme exposto nos referidos Termos e Condições de Uso, o descarregamento de títulos de acesso restrito requer uma licença válida de autorização devendo o utilizador aceder ao(s) documento(s) a partir de um endereço de IP da instituição detentora da supramencionada licença.

Ao utilizador é apenas permitido o descarregamento para uso pessoal, pelo que o emprego do(s) título(s) descarregado(s) para outro fim, designadamente comercial, carece de autorização do respetivo autor ou editor da obra.

Na medida em que todas as obras da UC Digitalis se encontram protegidas pelo Código do Direito de Autor e Direitos Conexos e demais legislação aplicável, toda a cópia, parcial ou total, deste documento, nos casos em que é legalmente admitida, deverá conter ou fazer-se acompanhar por este aviso.

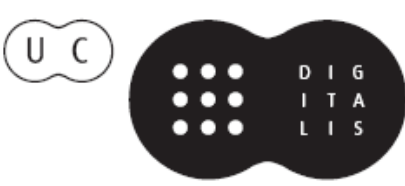




\section{Symposion and Philanthropia in Plutarch}

\section{José Ribeiro Ferreira, Delfim Leão Manuel Troster e Paula Barata Dias (eds.)}

IMPRENSA DA UNIVERSIDADE DE COIMBRA 


\title{
Dancing with Plutarch Dance and dance theory in Plutarch's Table TalK
}

\author{
Carlos A. Martins de Jesus \\ University of Coimbra
}

\begin{abstract}
The aim of this paper is to analyze Plutarch's discussion of the different kinds of ancient dance and their meaning in the Table Talk. Besides a large section from Book 9 (question 15), all of it concerning the parts of dance and their relation to poetry, we focus on those other moments where different rhythms of dance are discussed. Looking beyond the Plutarchan material, we search for the implications of this subject in terms of philantbropia and moderation, concepts extremely important in all nine books of the Table Talk.
\end{abstract}

The ancient symposium was a strictly staged social event at which members of the male elite drank, talked and enjoyed themselves, in a variety of ways. As for this last element, the convivial one, the various semiotic sources that have been preserved - mostly literature and painting ${ }^{1}$ - are clear on the importance given to many other elements besides eating and drinking. Music and poetry, inseparable arts, were a constant presence in ancient banquets, and the same should apply to dance.

As far as literature is concerned, there are many fragments from poems composed to be performed at banquets, at least from the middle of the seventh century BC onwards ${ }^{2}$. It is in the Odyssey (8.72-95) that we find what is probably the oldest western description of an aristocratic symposium, given by Alcinoos to Odysseus upon the latter's arrival ${ }^{3}$. In this passage we are presented with an aoidos singing the very beginnings of the Trojan War, which moves Odysseus to tears. But it is perhaps Herodotus (6.129.6-19) who gives us the first proof that banqueters not only enjoyed the dancer's art but also danced themselves, inspired by the wine and the artists' constant encouragement.

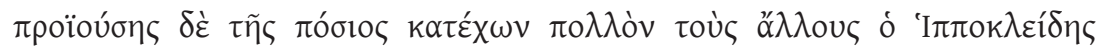

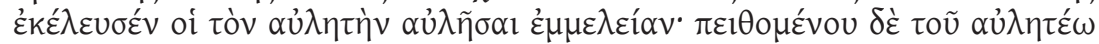

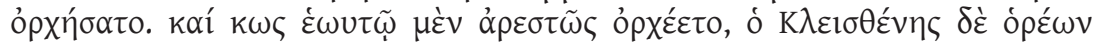

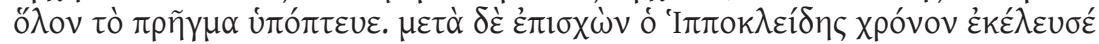

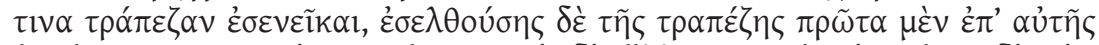

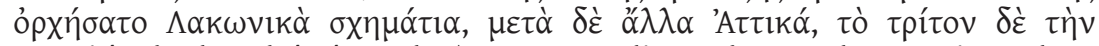

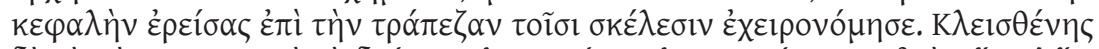

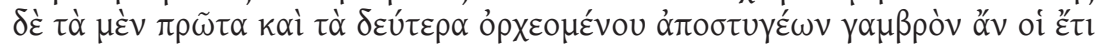

${ }^{1}$ W. J. Henderson, 2000, p. 6 defines and analyzes three different groups of testimony about the Greek symposium: sympotic poetry, vase-painting and archaeological remains from the banquet rooms themselves.

${ }^{2}$ On sympotic lyric, see W. J. Henderson, 1997. E. L. Bowie, 1986, p. 34 views the symposium as a privileged space for elegiac recitation, taking it as the beginning of the festive event itself.

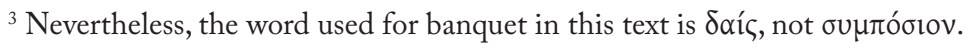




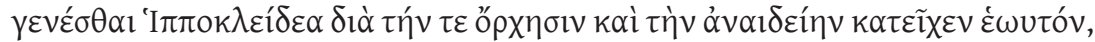

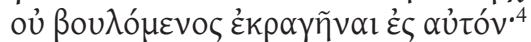

As they sat late drinking, Hippoclides, now far outdoing the rest, bade the fluteplayer play him music, and when the flute-player so did, he began to dance; and he pleased himself marvellous well with this dancing; but Cleisthenes saw the whole business with much disfavour. After a while, Hippoclides bade a table be brought; when it came he danced on it Laconian first and then Attic figures; last of all he rested his head on the table and made gestures with his legs in the air. Now Cleisthenes at the first and the second bout of dancing could no more bear to think of Hippoclides as his son-in-law, for his dancing and his shamelessness; yet he had held himself in check, not willing to vent his wrath on Hippoclides 5 .

In this passage, we read about the wedding-banquet offered by Cleisthenes to those who want to marry his daughter. One of them, Hippoclides, asks a

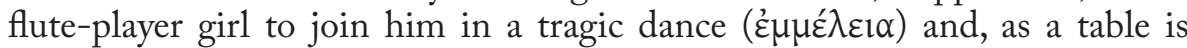
brought into the room, he dances on it some warrior-style Laconic steps and poses followed by (more comic) Attic ones. What is more, the sort of dance preferred at banquets is already the pantomimic one, as it will be in Plutarch's Table Talk. Also, in Herodotus' view, moderation is a priceless value to be taken into consideration at banquets. At the very last, Cleisthenes therefore refuses Hippoclides as a candidate for his daughter's hand, for he had been excessive in his performance. Relating to an earlier form of social arrangement - an aristocratic one - both examples may be no more than ancestors of the kind of symposium we find in Plutarch's Table Talk, still being an example of spaces of convivium in witch poetry, music and dance also played an important role. In other words, they are not supposed to be wise-men reunions, since the beginning thought to be a space of scientific and philosophical discussion, even if they actually enrich the elite banqueters with the gift of wisdom.

Before looking at sympotic poetry in more detail, let us point to yet another literary banquet, namely the one described in Xenophon's Symposium (2.15-

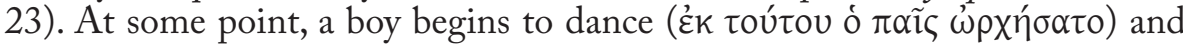
the banqueters, including Socrates, try to imitate him in a humorous scene. In this text - which Plutarch should have known very well - dance is only taken

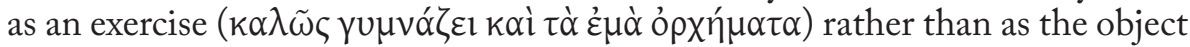
of deeper philosophical discussion, if only because Socrates admits that he is not a skilful dancer himself.

Beyond this, several poems from the Anacreontea, an anthology put together from the second century $\mathrm{BC}$ to the seventh $\mathrm{AD}$, express perfectly the space given to dance in the post-meal program of the banquet. For instance, poem 43 is a fine illustration of the joyful environment that should be usual at banquets:

\footnotetext{
${ }^{4}$ H. B. Rosén, Herodoti Historiae, vol. II. Leipzig, 1997.

${ }^{5}$ All translations are those of the Loeb Classical Library.
} 


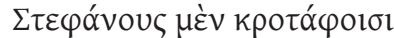

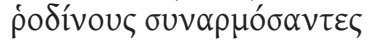

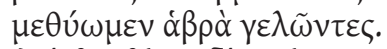

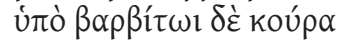

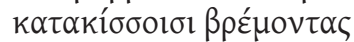

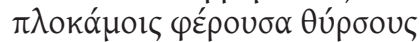

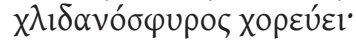

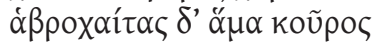

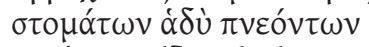

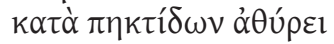

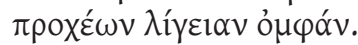

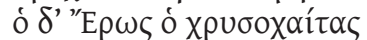

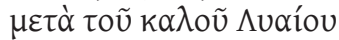

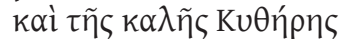

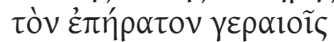

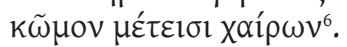

Let us fasten garlands of roses on our brows and get drunk, laughing gently. Let a gorgeous-ankled girl dance to the lyre carrying the thyrsus with its rich ivy tresses. With her let a boy, soft-haired and with sweet-smelling mouth, play the lyre, pouring forth a clear song. And golden-haired Love with beautiful Lyaeus and beautiful Cythere will join happily in the revel that old men find delightful.

No concern is shown here for moderation or good behavior. In fact, this idea is absent from the entire Anacreontic collection. Nevertheless, thanks to his own art and that of his imitators, Anacreon has become a real symbol of sympotic poetry; for the banquet is the special context of most of these poems, a space where Eros, wine, music and dance among drinking men with garlands around their heads are very important elements.

Equally rich testimony is given by Greek vase-painting. Besides their frequent use at the banquet, they usually show sympotic scenes, both mythological ones and episodes from daily life ${ }^{7}$. Moreover, the physical rooms where the event took place were often decorated with sympotic motifs. The most widely known one is probably the so-called Swimmer Tomb Room in Paestum, which was indeed a dining room. On its four walls we see the guests, servants and even a komos with a flute-player girl and other artists that could in fact perform some dance steps ${ }^{8}$.

The relevance of this evidence on the Greek symposium to Plutarch is that all the sympotic descriptions that he created (or recreated, we cannot be

${ }^{6}$ To quote the Anacreontea, we use the text of M. L. West, Carmina Anacreontea, Leipzig, 1984. Numbers $2,15,38,40,42,47$ and 59 of the collection also mention dance in a sympotic environment.

${ }^{7}$ For three examples, clearly related to banquets, see L. B. LAwLER, 1964, pp. 119-20.

${ }^{8}$ In the Roman period, too, the walls of banquet rooms were painted with sympotic motifs, as in the case of the Triclinium House in Pompeii. See K. M. D. Dunbabin, 2003, pp. 52-60 and plates I-III. 
sure) in the nine books of his Table Talk are consciously Greek. Inspired by the banquets of wise men portrayed by Plato, Xenophon and others that have not come down to us - yet very different from those archaic symposia we find in the Homeric poems -, the Plutarchan convivium is designed to imitate Greek ways of drinking, eating and enjoying entertainment. In a joyful party environment, where philosophy is mixed with more trivial issues, singing and dancing would have been part of the post-meal program. Nevertheless, nowhere in the book do we find any detailed description of a dance performance, except maybe the allusion to a dance contest in Book 9 (question 15), to which we shall soon return. Just like the rest of the speakers, Plutarch is more interested in discussing which dance styles are more appropriate to the wise men's banquets, recurring all the time to the opinion of those Greek authors who dealt with the subject, most notably Plato and Xenophon.

The subject of dance appears first in Book 1 of the Table Talk (614D-E), at a moment when the discussion focuses on the philosophic argumentation most suitable to a banquet. The dance is then used in the following metaphor:

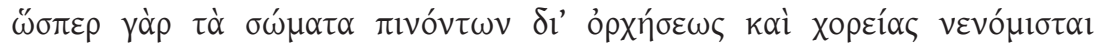

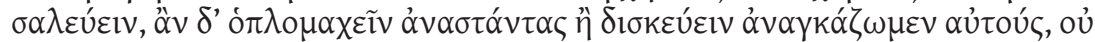

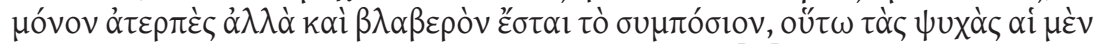

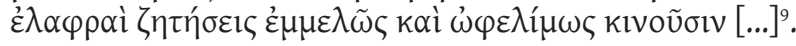

For just as the bodies of men who are drinking are accustomed to sway in time with pantomimic and choral dancing, but if we compel them to get up and exercise in heavy armour or throw the discus, they will find the party not only unpleasant but even harmful, just so their spirits are harmoniously and profitably stirred by subjects of inquiry that are easy to handle...

The metaphor serves to prove how frequently dance was a part of banquets, because it is only this frequency that allows it to be used as an example of something common. Going one step further, we may see how moderation, in relation to dance, is Plutarch's major concern. It must not be allowed to confuse or even distract the company from the path of reason, thus preventing the event from becoming "not only unpleasant but even harmful" (oủ $\mu$ óvov

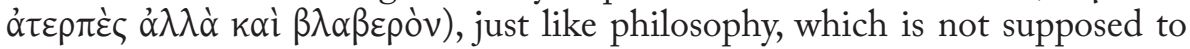
compromise the good mood, by being too serious or too deep.

Further on in Book 7 (705A), in a discussion of good and bad music, dance is again a subject of conversation. It is cited as a parallel when Calistratus distinguishes between pleasures of the body and those of the soul:

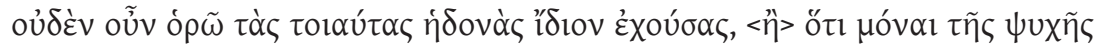

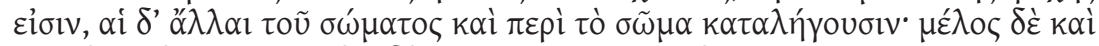

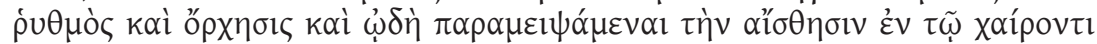

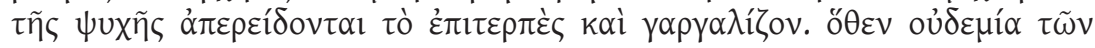

\footnotetext{
${ }^{9}$ For the Greek text of the Table Talk, we use C. Hubert, Plutarchus. Moralia, IV, Leipzig,
} 1971. 


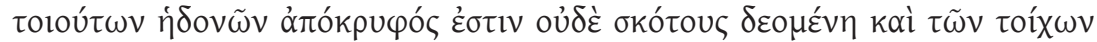

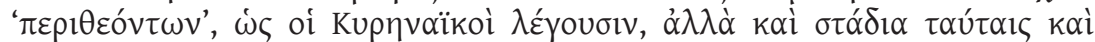

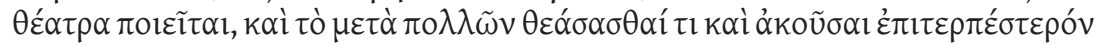

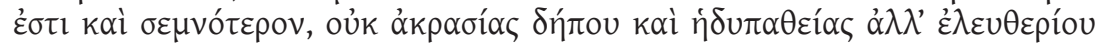

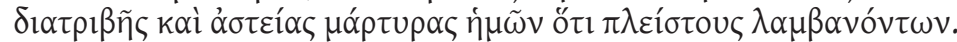

I do not see that pleasures of this sort have anything special about them, except that they alone have to do with the mind, whereas the rest are pleasures of the body and reach and end in the body. Melody, however, and rhythm and dance and song go on past sense-perception and find a basis for their pleasing and enticing quality in the mind's faculty of enjoyment. Thus none of the pleasures of this kind is secret or requires darkness or walls 'running round' (as the Cyrenaics say), but stadia are even built for them, and theatres; and to witness a spectacle of sight or sound in a large company is considered more enjoyable and more impressive because we are associating as many persons as possible with ourselves, surely not in incontinence and sensuality, but in a liberal and civilized pastime.

While the so-called bodily pleasures are given by the sensory organs of perception, the pleasures of the soul are given by sight and hearing, being far beyond the sensual stage of knowledge, as well as free from excess. This is why dance and music are included in this last group. Lamprias does not agree, thinking that the pleasures of the soul have a truly charming power that undermines both reason and good judgment, leading a man to excess

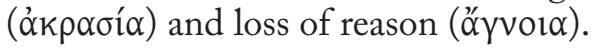

Having proved the need for a moderate enjoyment of pleasures, in banquets as in all human life, in the eight question of Book 7 (711E-F), Plutarch goes on to discuss precisely what kind of amusement is welcome at a banquet. With

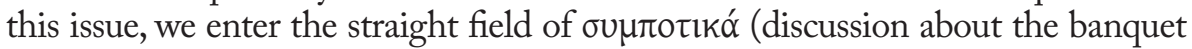
itself), which is different from $\sigma \cup \mu \pi$ roøaká (discussion about several subjects, only in the context of a banquet), an expression that gives the title to the entire work.

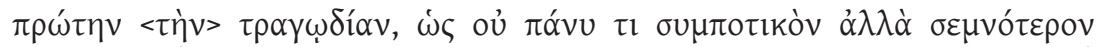

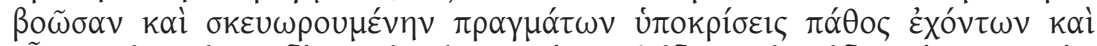

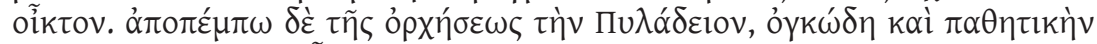

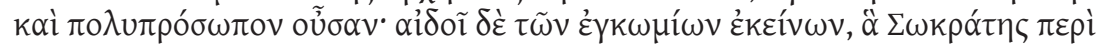

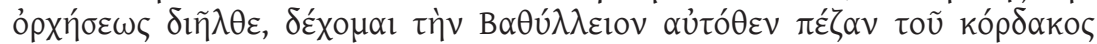

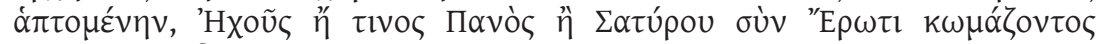

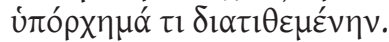

First of all, tragedy: it is not at all appropriate to a party, with its majestic elocution and its elaborated representation of events that are moving and sorrowful. As for dances, I should disqualify the Pylladic, as pretentious and emotional and requiring a large cast; but out of respect for Socrates'well-known praise of the dance, I will accept the Bathyllic. It is a straightforward unaccompanied dance, verging on the kordax, and presents a danced interpretation of Echo or some Pan or Satyr reveling with Eros. 
Diogenianus intends to exclude tragic performances from the banquet for

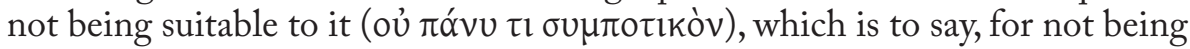
convenient to the good mood of the event - the same point that had been made about philosophy before. This is a strongly Platonic way of thinking ${ }^{10}$, which is also present elsewhere in Plutarch's works ${ }^{11}$. Talking about dance, he then excludes the so-called Pylladic dance, yet accepts the Bathyllic one, a local rhythm which he describes as being very similar to the Greek kordax. As for Pylades ( $1^{\text {st }}$ century BC), we know that he was from Cilicia and that he introduced important changes to tragic pantomime, making it more exuberant and emotional by means of a sophisticated choreography and a larger number of characters ${ }^{12}$. Suetonius (Aug. 45. 4) actually says that Pylades, along with Bathyllus, gave a new shape to Roman pantomime, with both men becoming the founders of the so-called "Italic dance"13. Athenaeus (20d-e), the richest and most comprehensive source we have about both artists' style, talks about Pylladic dance in a strikingly similar way. Thus, we may conclude that he and Plutarch followed the same sources, perhaps Seleucus and Aristonicus, who are the ones identified by Athenaeus himself. As for Bathyllic dance, it is described as being very similar to the Greek kordax, as it is in Plutarch, but mixed with satirical elements:

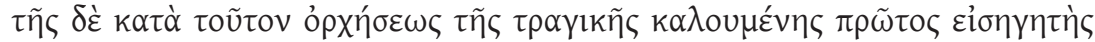

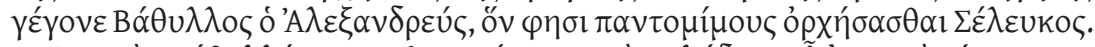

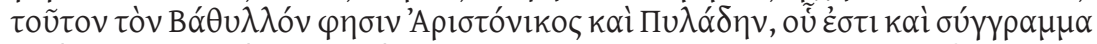

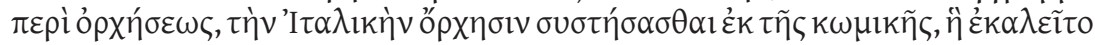

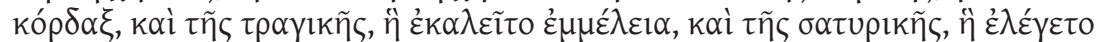

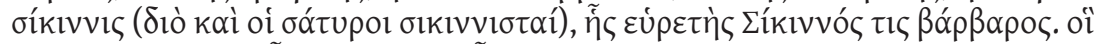

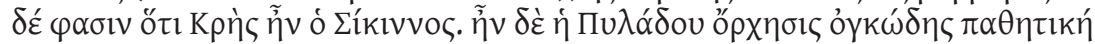

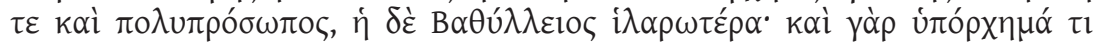

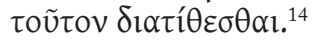

Now the first to introduce this "tragic dancing", as it was called, was Bathyllus of Alexandria, who, as Seleucus says, danced in pantomime. Aristonicus says that this Bathyllus, together with Pylades, who wrote a treatise on dancing, developed the Italian style of dance out of the comic fling called the cordax, the tragic measures called emmeleia, and the satyr rout called sicinis (whence the satyrs are also called sicinnistae), the inventor of which was a barbarian named Sicinnus. But others say Sicinnus was a Cretan. Now Pylades' dancing was solemn, expressing passion and variety of character, whereas Bathyllus' was more jolly; in fact he composed a kind of hyporcheme.

${ }^{10}$ See P1., Cra. 408c; Grg. 502b; Smp. 194b; Lg. 659 a-c, 700d - 701b, $876 f$.

${ }^{11}$ Quaest. conv. 724D; De facie 926C; De aud. 41f.

${ }^{12}$ Two epigrams from the Greek Anthology are very encomiastic about Pylades' art: 9. 248 and 16.290.

${ }^{13}$ On this issue, see E. J. Jory, 1981.

${ }^{14}$ The Athenaeus' text is quoted from C. B. Gulick, Athenaeus. The Deipnosophists, 7 vols., Cambridge, Mass., 1927-1941. 
Athenaeus makes a clear distinction between both artists' style, especially in relation to their tone -the first more pathetic, the second more joyful -, and that is also the reason why Plutarch seems to distinguish them, rejecting one and accepting the other. The explanation for this is perhaps to be found in Athenaeus' text when he says that Bathyllus' dance is i $\lambda \alpha \rho \omega \tau \varepsilon$ e $\rho \alpha$ ("more jolly") - a quality that must be taken into consideration, according to Plutarch's morality, along with at least two others, decency and moderation. In fact, we know that Pylades became famous for the mimic adaptation of mythical-tragic histories ${ }^{15}$, and it should not be forgotten that Diogenianus himself, earlier in the text, had already excluded tragedy from banquets (771E). Moreover, the very same Diogenianus is clear about the fact that he only accepts the Bathyllic dance "out of respect for Socrates' well-known praise of the dance". This seems to be an obvious reference to Xenophon's text (Smp. 2. 16-19), where, nevertheless, only the good effects of the dance on the body, as a physical exercise, are at issue, whereas no reference at all is made to the moral implications that are Plutarch's almost exclusive concern.

It seems certain at any rate that, when we talk about dance in the Table Talk, we are actually talking about pantomime, that dramatic way of expression without words, where only body movements, poses and the characters' outlook, along with music and maybe some non-verbal sounds, are the means to perform mythological or daily-life episodes ${ }^{16}$. Significantly, it is the same art that is deeply analyzed in Book 9, in the very last question of the work, which is all dedicated to the parts of the dance and its relation to poetry. The context that provokes the discussion is simple: a dance performance of the Pyrrhic offered to the guests after dinner, in which Lamprias, Plutarch's brother, was appointed, along with the trainer, to be the judge, on the strength of his past record of excellence as a dancer ${ }^{17}$. It is important to observe that this style also fits into the pantomimic group of dances, which has been discussed at length. In fact, it was originally the mimic dance representation of a fight, performed by armed dancers, which was in itself a good form of entertainment and exercise for the soldiers ${ }^{18}$. A fragment from Aristoxenus of Tarentum ( $4^{\text {th }}$ century BC), a Peripatetic philosopher who wrote about music and rhythm, defines how the Pyrrhic must have been in its origins (fr. 103 Wehrli = cit. Athen. 630c):

${ }^{15}$ Take, for example, his performance of Hercules Furens, as reported by Macrobius (Sat. 2. 7. 12-19). On the subjects of pantomimic representation see E. J. Jory 2008, pp. 157-168.

${ }^{16}$ From the wealth of recent scholarly work on pantomime, see I. LADA-RicHARDs, 2007, R. Webb, 2008 and E. Hall \& R. Wyles, 2008.

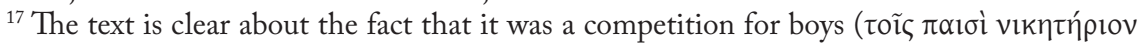

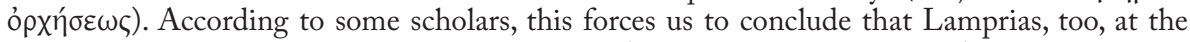
aforementioned banquet, must have been a boy (perhaps even a young boy). For this reason, S.-T. Teodorsson, 1989, 3, p. 375, thinks that this sympotic reunion must have taken place in AD 66/67. Nevertheless, we still think it is a forced conclusion to assume that, being appointed as judge, Lamprias should be a $\pi \alpha \tilde{i} \varsigma$ or a $\mu \varepsilon ı$ ók kıov at the time of the banquet.

${ }^{18}$ X., An. 6.1.5-13 alludes to this function of the Pyrrhic dance. 


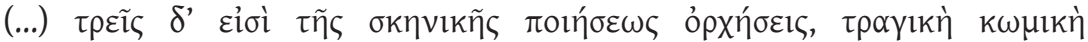

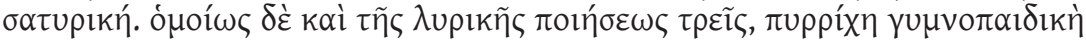

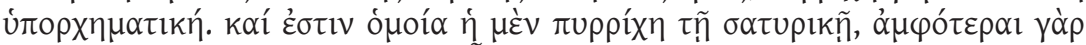

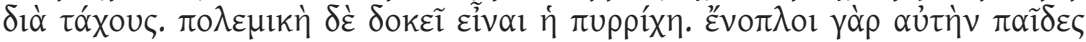

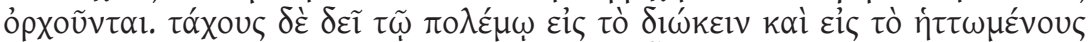

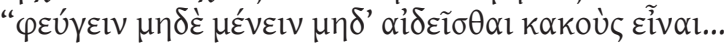

... three are the dances of scenic poetry: tragic, comic and satirical. Also three are the lyric ones: pyrrhic, gymnastic and that of hyporchemae. Just like the Pyrrhic is the satirical, they are both based on basic steps. In fact, boys dance it armed. In war it is necessary to be fast in pursuit but also, for those who are defeated, to run and never stop or feel ashamed for being cowards.

Apparently, the dance gradually lost its warrior meaning. This seems to be implicit in the paragraph from the Table Talk we are discussing, where the winners are even given a cake as a prize. Nevertheless, it would still be an important part of the athletes' training in fight schools, especially at Sparta. As for the rest of the Greek world, however, it should have become mostly a Dionysiac dance. This is suggested by Athenaeus 631a-b, perhaps the best testimony we have about what dance must have been like in Plutarch's times:

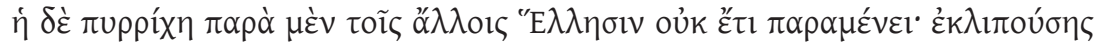

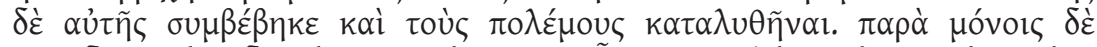

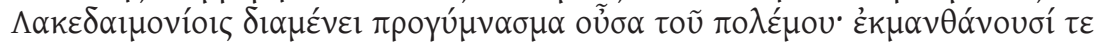

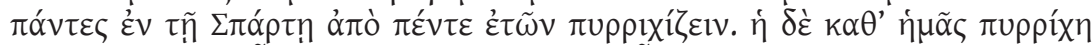

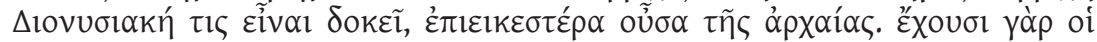

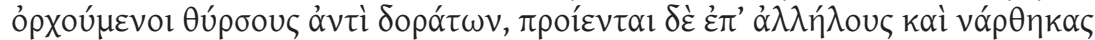

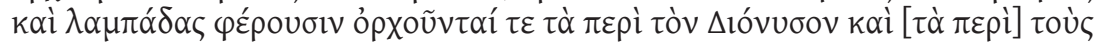

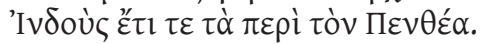

The pyrrichê, however, no longer survives among other Greeks, and coincidently with its decline the wars stopped. But among the Spartans alone it still persists as a preparatory drill for war; further, all males in Sparta, from five years of age on, learn thoroughly how to dance the pyrrichê. The pyrrichê of our times is rather Dionysiac in character and is more respectable than the ancient kind. For the dancers carry Bacchic wands in place of spears, they hurl also at one another stalks of fennel, they carry torches, and dance the story of Dionysus and India, or again the story of Pentheus.

Athenaeus' text proves that the Pyrrhic was still a mimic dance, representing at that time not the battles of men, but rather the histories of the gods, especially those related to the Dionysiac cult. And it was in this new disguise - which is only thematic - that the Romans received it.

Ammonius, whose intersemiotic theory of dance occupies the remainder of the book, advocates its analysis in three different but still complementary stages, which prove once more that the issue under discussion is pantomime. 
They are $\varphi \circ \rho \alpha ́$, $\sigma \chi \tilde{\eta} \mu \alpha$ and $\delta \varepsilon \tilde{\imath} \xi\llcorner\zeta$, tentatively to be translated as "phrase" ("movement", or even "coordination"), "figure" (or "pose") and "indication" $(747 \mathrm{~B}-\mathrm{C})^{19}$ :

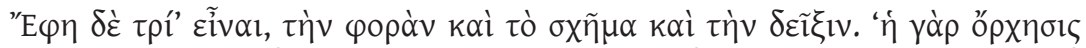

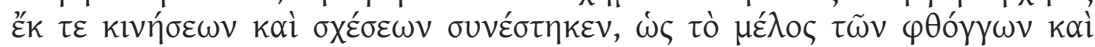

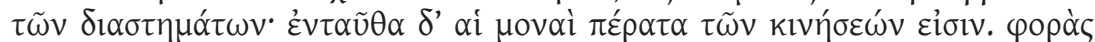

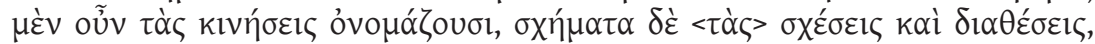

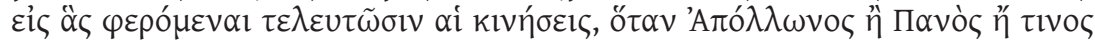

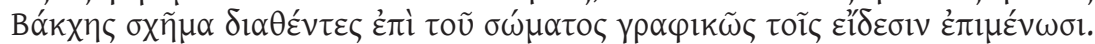

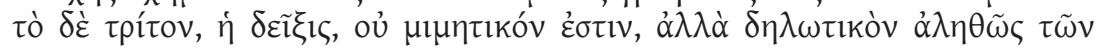

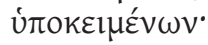

[which] he said were three in number: the phrase, the pose, and pointing. "Dancing", he explained, "consists of movements and positions, as melody of its notes and intervals. In the case of dancing the rests are the terminating points of the movements. Now they call the movements 'phrases', while 'poses' is the same of the representational positions to which the movements lead and in which they end, as when dancers compose their bodies in the attitude of Apollo or Pan or a Bacchant, and then retain that aspect like figures in a picture. The third element, pointing, is something that does not copy the subject-matter, but actually shows it to us.

Just like the poet uses onomatopoeia and metaphors to represent reality, the dancer may use movement and pose to mime any situation or even narrative. As for $\delta \varepsilon \tilde{\imath} \xi i \varsigma$, which is said to be a non-mimetic concept of dance (oủ $\mu \iota \eta \tau \imath \kappa o ́ v ~ \varepsilon ́ \sigma \tau \imath v)$, some additional considerations are called for. Indeed, Plato did not distinguish between movement and pose, always taking dance as the art of representing speech visually ( $L g$. 816), as did Aristotle (Poet. 1447a 24). As L. B. Lawer (1954, pp. 155-157) pointed out, when studying the uses of $\delta \varepsilon \tilde{l} \xi 15$ and other words of the same root, they always have some mimetic sense. This leads us to agree with S.-T. Teodorsson (1983, 3, p. 379), when he says that "Plutarch's source may have been a treatise written by a musician or a rhetorician of Peripatetic outlook, who tried to describe dancing as an expressive for parallel to speech and analysable into basically the same elements as speech, as well as those of music".

Still, one may ask how we are to read $\delta \varepsilon \tilde{\imath} \xi 1 \zeta$ in this very special context. It seems that Ammonius views dancing as a way either to imitate things, by means of a static pose or movements, or simply to point at them, by indicating them to the spectator, the latter corresponding to the aforementioned nonmimetic concept of dance. Let us give an example: a dancer can imitate the pose or the movements of an animal - let us say, a swan - or simply point at a statue of the very same creature close to him.

Bearing this in mind, one can now understand that the discussion is focused entirely on Pyrrhic dance, only in its non-warrior version, rather

\footnotetext{
${ }^{19}$ A thorough study of these concepts is made by L. B. LAwER, 1954.
} 
the later Dionysiac one. Moreover, the initial reference to the Pyrrhic dance performed by Lamprias no longer appears to be a simple digression, as some scholars have argued ${ }^{20}$.

Indeed, that triple comparison between dance, poetry and painting is what moves Ammonius to quote one of the most famous of Simonides' ancient apophthegmata ( $6^{\text {th }}$ century BC), according to which that poet would have been the first to establish the parallel between poetry and music. In the following words Plutarch quotes that detail of the poet's tradition (De glor. Athen. $346 \mathrm{~F})^{21}$ :

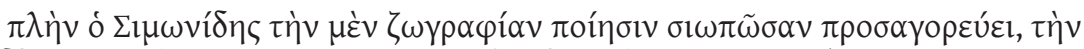

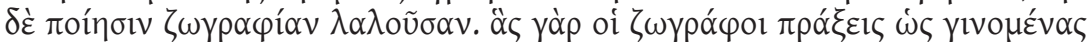

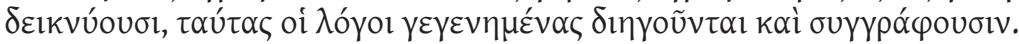

Simonides, however, calls painting inarticulate poetry and poetry articulate painting: for the action which painters portray as taking place at the moment literature narrates and records after they have taken place.

And here is how Ammonius intends to deny it in the Table Talk (748A-B):

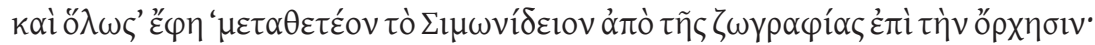

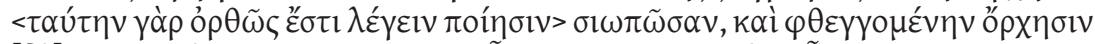

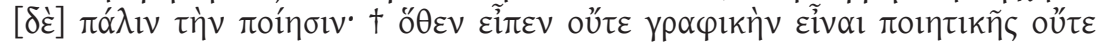

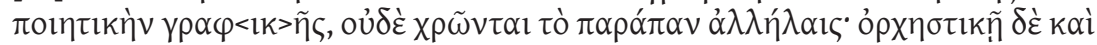

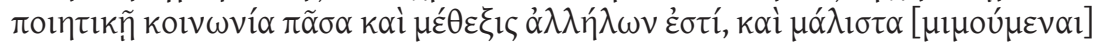

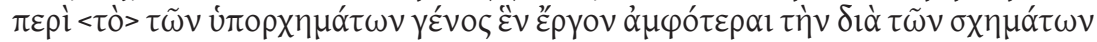

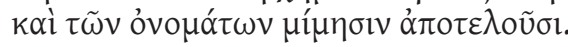

In short, one can transfer Simonides' saying from painting to dancing, <rightly calling dance> silent poetry and poetry articulate dance. There seems to be nothing of painting in poetry or of poetry in painting, nor does either art make any use whatsoever of the other, whereas dancing and poetry are fully associated and the one involves the other. Particularly it is so when they combine in that type of composition called byporchema, in which the two arts taken together effect a single work, a representation by means of poses and words.

Poetry and dance are indeed a kind of imitation of reality. The very best poetical genre to accomplish this is the byporchema, a performance based on the songs and dances of a chorus that, according to its ancient characterization, should have gathered around some god's altar, at the time when the victims were sacrificed ${ }^{22}$. The dance figures $(\sigma x \eta ́ \mu \alpha \tau \alpha)$ stand for the words (or names,

${ }^{20}$ According to S.-T. Teodorsson, 1989, 3, p. 374, for example, "at the beginning of the talk the pyrrhic dance is mentioned as an introduction, while the subsequent speech delivered by Ammonius (...) concerns above all the contemporary pantomime."

${ }^{21}$ The same apophthegma is mentioned in De aud. $17 \mathrm{~F}$ and De ad. et am. 58B.

${ }^{22}$ On the byporchema see A. M. DALE, 1950. 
o $v o ́ \mu \alpha \tau \alpha)$ in poetry, similar elements from two different semiotic codes serving

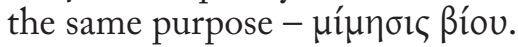

Some conclusions may finally be drawn from this analysis of dance in the Table Talk. First of all, it was a regular part in both private and social banquets, which Plutarch represents - at least in a literary sense - in the Greek way. Then, as it is impossible to trace exactly which were Plutarch's sources on this issue - in which he seems to be far from Plato and Aristotle -, the discussion focused mostly on pantomime, the most famous style in those days. It is in fact this style that allows us to conduct an intersemiotic study in the Table Talk, taking in parallel dance, poetry and painting and looking at what they have in common - the fact that they all are $\mu$ íunors Bíov or, to use Aristotle's

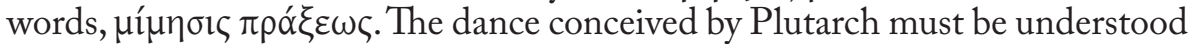
in a dramatic sense, being close to the performance of a play; and that is why Aristotle's theories on tragedy are so important to understand his point of view. Above all this, as a guiding idea, stands the supreme ideal of moderation, which does not allow excesses or deviations, a pregnant concept in all the banquets (re)created by Plutarch.

One question is still worth asking: why does Plutarch choose to end an entire philosophical work like the Table Talk on such a frivolous issue as is dance theory ${ }^{23}$ ? Maybe because it is not a frivolous issue at all, as it may seem at first sight. It appears that dance is an intermediate discipline, a kind of study and practice not for actual philosophers or philosophy students, but still capable of providing a discussion mostly based on Plato's theories on body and soul, besides being an issue perfectly suitable to the sympotic environment. On this, one should remember Plutarch's own words in Coniugalia Praecepta (145C):

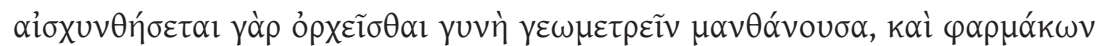

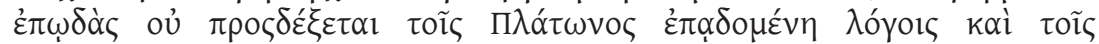

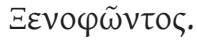

For a woman studying geometry will be ashamed to be a dancer, and she will not swallow any beliefs in magic charms while she is under the charm of Plato's or Xenophon's words.

If dancing is not a deep philosophical issue, dance theory can certainly be one, based as it is mostly on ethics and morality ${ }^{24}$. Although Plutarch seems to refuse to give his Table Talk a very complex end, he chooses to give it one that is still capable of launching the discussion of deep philosophical questions that are traceable through the entire work.

${ }^{23}$ We would like to thank Professor Philip Stadter, who posed us this very same question after the presentation of this paper.

${ }^{24}$ I. LADA-Richards, 2008,pp. 285-313 focuses on the ethical and moral role of pantomime, asking - in the very title of her paper - "Was pantomime 'good to think with' in the ancient world?". 


\section{WORKS CITED}

Bowie, E. L., "Early Greek elegy, symposium and public festival", JHS, 106 (1986) 13-35.

Dale, A. M., "Stasimon and hyporcheme”, Eranos, 48 (1950) 14-20.

Dunbabin, K. M. D., The Roman banquet. Aspects of conviviality. Cambridge, 2003.

Henderson, W. J., “Elegie en sumposion”, Akroterion, 41.2 (1997) 4-22.

"Aspects of the ancient Greek symposion", Akroterion, 45 (2000) 6-26.

Jory, E. J., "The literary evidence for the beginnings of Imperial pantomime”, BICS, 28 (1981) 147-61.

"The pantomime dancer and his libretto", in Hall, E. \& Wyles, R. (eds.), New directions in ancient pantomime. Oxford, 2008, pp. 157-68.

Lada-Richards, I., Silent Eloquence. Lucian and pantomime dancing. London, 2007.

"Was pantomime 'good to think with' in the ancient world", in HaLL, E. \& Wyles, R. (eds.), Nerw directions in ancient pantomime. Oxford, 2008, pp. 285-313.

Lawer, L. B., "Phora, schema, deixis in the Greek dance", TAPhA, 85 (1954) $148-58$.

Teodorsson, S.-T., A commentary on Plutarch's Table Talk (3 vols.), Göteborg, 1989.

Webb, R., Demons and Dancers. Performance in Late Antiquity. Cambridge/ Mass., 2008. 